\title{
CONTEMPORARIEST SYMBOLICS PADA PERILAKU BISNIS PEDAGANG DI LINGKUNGAN PASAR TRADISIONAL
}

\author{
Saudah \\ Program Studi Ilmu Komunikasi FISIP Universitas Merdeka Malang \\ saudah@unmer.ac.id
}

Abctract

Trader's business behavior in the traditional market environment is reflected in the behavior that appears in the interaction built with other parties. The uniqueness that is highlighted is the trade situation that can not be separated from face to face communication directly, began to be supported by advances in the field of communication technology. Contribution in building interaction among the parties involved is able to generate trust so that communication occurs continuously. What is in the business of the traditional market shows a recognizable and recognizable identity, by seeing the communication style of the merchant, the utilization of the communication tool, the accessories used, and the means of transportation. They are all symbols inherent in the life of the merchant, reflecting the life of the merchant. Meaning of the symbol by others is not much different, because people have the ability to give meaning and assessment of a person. This is the uniqueness of the merchant that is reflected in the daily behavior in the traditional market environment.

Keywords: Symbols, Traders, Traditional Markets

\begin{abstract}
Abstrak
Perilaku bisnis pedagang di lingkungan pasar tradisional tercermin dari perilaku yang nampak dalam interaksi yang dibangun dengan pihak lain. Keunikan yang ditonjolkan adalah situasi perdagangan yang tidak terlepas dari komunikasi tatap muka secara langsung, mulai didukung oleh kemajuan dibidang teknologi komunikasi. Kontribusi dalam membangun interaksi diantara pihak-pihak yang terlibat adalah mampu memunculkan kepercayaan sehingga komunikasi terjadi secara berkelanjutan. Apa yang ada dalam diri pelaku bisnis di pasar tradisional menunjukkan identitas yang bisa diingat dan dikenali, dengan melihat gaya berkomunikasi dari pedagang, pemanfaatan alat komunikasi, aksesoris yang digunakan, serta alat transportasi yang dimiliki. Kesemuanya itu adalah simbol yang melekat dengan kehidupan pedagang, sehingga mencerminkan kehidupan pedagang. Pemaknaan terhadap simbol tersebut oleh orang lain tidak jauh berbeda, karena masyarakat memiliki kemampuan dalam memberi makna dan penilaian terhadap diri seseorang. Inilah keunikan yang dimiliki pedagang yang tercermin dalam perilaku keseharian di lingkungan pasar tradisional.
\end{abstract}

Kata Kunci: Simbol, Pedagang, Pasar Tradisional 


\section{PENDAHULUAN}

Kajian komunikasi hingga saat ini memainkan peran penting dalam setiap lini kehidupan masyarakat. Dari tatanan personal hingga bermedia, akan selalu dikaitkan dengan kemampuan/kecakapan berkomunikasi dari masing-masing individu. Sejauh ini, komunikasi adalah mata rantai kehidupan, yang akan selalu kembali ke pemikiran dasar bahwa manusia tidak akan lepas dari label makhluk sosial. Kebutuhan untuk selalu berkomunikasi dengan yang lain adalah harapan yang tidak boleh padam. Selama manusia saling membutuhkan, maka keberadaannya akan memiliki arti bagi orang lain. Kebutuhan akan berkomunikasi adalah nyata dan akan terus berlanjut untuk bisa merasakan bahwa manusia itu terdiri dari beberapa aspek yang saling berkaitan. Manusia akan senantiasa bergaul dengan orang lain untuk memenuhi kebutuhan-kebutuhannya, dari hal yang sederhana sampai yang kompleks. Kehadiran orang lain juga akan mendorong seseorang untuk membangun komunikasi secara berkelanjutan, sehingga mampu mewujudkan peran secara bersama.

Totalitas dalam diri manusia adalah mampu memainkan peran dalam setiap perjumpaan dengan individu lainnya. Masing-masing akan mampu memberikan persepsi terhadap bentuk komunikasi yang dijalankan, terutama pada bahasa non verbal yang bisa menyiratkan arti tersendiri. Kemampuan manusia dalam memahami dirinya, diri orang lain serta lingkungannya adalah merupakan totalitas diri seorang manusia. Saat ini, tuntutan untuk mengembangkan diri tidak lain adalah untuk memberikan kemanfaatan bagi dirinya dan nanti akan bisa berpengaruh terhadap orang lain. Situasi komunikasi yang dihadapi oleh seseorang, pastinya akan berkaitan dengan motif seseorang dalam membangun interaksi dengan orang lain. Motif melikupi semua penggerak, alasan, atau dorongan dalam diri manusia yang menyebabkan manusia berbuat sesuatu dan untuk memahami dorongan motif, bisa dilihat dari riwayat dan struktur kepribadian, perilakunya, kondisi lingkungan dan keterkaitan diantara ketiganya (Gerungan, 2004:151).

Selain membangun interaksi dengan motif tertentu, dalam diri manusia juga ditegaskan adanya perilaku yang menyiratkan bahwa ada kesadaran dalam upaya untuk membangun dan mengembangkan hubungan dengan orang lain. Begitu juga dalam sebuah bisnis, yang pastinya saling membutuhkan satu sama lain, terutama untuk keberlanjutan bisnis yang sedang dijalankan. Kondisi sekarang ini menunjukan bahwa pergerakan bisnis semakin menggeliat sehingga keterlibatan masyarakat sangat tinggi, baik sebagai pelaku bisnis maupun pihak yang mendapatkan kemudahan dengan adanya bisnis tersebut. Berbagai bidang bisnis dapat ditemui dengan mudah, dan sekarang ini masyarakat sudah semakin pandai memanfaatkan peluang bisnis. Kreatifitas dalam berbisnis dipicu dengan keinginan untuk mencapai sebuah tujuan, baik jangka pendek maupun jangka panjang.

\section{TINJAUAN PUSTAKA}

\section{Perilaku Bisnis dalam Kajian Komunikasi}

Berbagai bentuk bisnis yang saat ini digeluti oleh masyarakat, tetap memperhitungkan serta membutuhkan keahlian dalam berkomunikasi. Keahlian dalam bidang komunikasi tidak hanya sebatas pada kemampuan berbicara, tetapi akan dipadukan dengan kemampaun olah non verbal. Konsumen yang akan ditemui bermacam-macam, dan masing-masing 
dengan pembawaan diri yang unik, sehingga untuk bisa membangun kerjasama maka diperlukan keahlian dalam berkomunikasi. Salah satu kegiatan menukarkan informasi dalam lingkup bisnis dengan didasari oleh tujuan tertentu serta disajikan dengan berbagai medium komunikasi adalah bagian dari komunikasi bisnis. Pertukaran informasi bisa dengan cepat dilakukan, dan biasanya dilakukan secara terus menerus untuk mendapatkan hasil yang maksimal. Dalam kurun waktu tertentu, sebuah bisnis yang sudah direncanakan, akan menentukan strategi untuk mengembangkan bisnis, meningkatkan dan memperjuangkan untuk bisa bersaing dengan yang lain.

Salah satu unsur penting dalam bisnis adalah ukuran kejujuran yang semakin beragam. Berbagai strategi digunakan untuk bisa meraih konsumen dan berupaya mempertahankannya. Kondisi ini yang menyebabkan munculnya perilaku yang beragam. Yang patut menjadi perhatian adalah perilaku bisnis masyarakat lebih melihat kemanfaatan yang didapatkan, tidak hanya dari aspek materi tetapi juga membangun hubungan yang lebih meningkat. Terbangunnya hubungan ini menunjukkan bahwa bisnis juga membawa nilai positif.

Selain munculkan bisnis modern, toko modern, yang tetap bisa menjaga eksistensi hingga saat ini adalah pasar tradisional. Kehadirannya begitu dekat dengan masyarakat untuk bisa memenuhi kebutuhan khususnya kebutuhan seharihari. Dengan ciri khas yang tidak dimiliki pasar modern, tetap bisa menunjukkan bahwa kehadirannya tetap dinanti oleh masyarakat, karena ada keterlibatan perjumpaan secara langsung dalam proses jual beli yang berujung pada kesepakatan harga kedua belah pihak membawa kepuasan sendiri. Tentunya, dengan komunikasi yang dibangun antara penjual dan pembeli akan dimungkinkan terjadinya perjumpaan berikutnya di situasi yang sama yaitu di pasar tradisional, atau juga pada situasi lainnya. Sedangkan situasi dimana terjadi interaksi sosial dapat disebut sebagai situasi sosial. M. Sherif dalam Gerungan (2004:78) membagi situasi sosial dalam dua golongan utama. 1) Situasi kebersamaan, dimana individu-individu yang turut serta dalam situasi tersebut belum mempunyai hubungan yang teratur. Dapat dikatakan sebelumnya belum saling mengenal sehingga interaksi belum mendalam; 2) situasi kelompok sosial, yang merupakan situasi di dalam kelompok, dan ada hubungan yang lebih mendalam.

Perilaku bisnis juga tergambarkan sebagai sebuah ciri khas yang melekat dalam pribadi seseorang untuk bisa mempertimbangkan nilai untung dan rugi dari aktivitas yang dilakukan tanpa meninggalkan etika yang berlaku. Satu hal yang mendasarinya adalah kemampuan mengendalikan diri terhadap situasi yang akan dihadapi dalam lingkungan bisnis. Dengan melihat bahwa kegiatan bisnis juga mengutamakan adanya kejujuran, karena membangun relasi tidaklah sederhana dan untuk mempertahankannya membutuhkan strategi. Nilai kejujuran ini akan berkaitan erat dengan integritas dari pelaku bisnis yang mengedepankan kepercayaan serta memegang teguh prinsip untuk melakukan kegiatan secara terhormat. Membangun relasi tersebut juga didasari etika pergaulan yang baik, sehingga perilaku yang nampak pasti akan positif.

Perilaku dipahami sebagai sebuah tindakan atau aktivitas seseorang, yang didalamnya juga terjadi proses berpikir, berpendapat, bersikap dan bisa diwujudkan 
secara kongkrit. Perilaku bisnis ini mengacu pada tindakan yang dilakukan seseorang dalam kegiatan usaha sampai pada tahapan menjaga eksistensi dari usahanya dalam kompleksitas situasi di tingkatan masyarakat yang semakin modern. Perilaku bisnis juga tidak dapat ditawar lagi, karena saat ini keterbukaan informasi dengan didukung berbagai medium menjadi salah satu cara untuk mampu bertahan di dunia bisnis. Perilaku yang baik dalam konteks bisnis adalah perilaku yang sesuai dengan nilai-nilai yang terkandung di masyarakat.

Perilaku yang melekat dalam diri seseorang juga erat kaitannya dengan kemampuan untuk mengkomunikasikan setiap pandangan, pemikiran serta memberikan sebuah keputusan terhadap aktivitas bisnis yang dilakukan sehingga mampu menjawab keinginan dari masyarakat.

\section{Konteks Relasi Pedagang di Pasar Tradisional}

Pedagang adalah satu bagian dari pasar yang memiliki kontribusi besar dalam upaya keberlangsungan aktivitas perdagangan. Jika memperbincangkan pasar tradisional, maka pedagang adalah motor pengerak utama atau penopang bagi tumbuh kembangnya ekonomi di sebuah wilayah. Kehidupan pedagang tidak ada habisnya untuk diperbincangkan. Dengan ciri khas yang melekat pada kehidupan pedagang, menjadikannya sosok yang mampu membangun interaksi secara langsung dan dengan segera mengeluarkan potensi yang ada ketika pembeli datang. Komunikasi yang dibangun pedagang secara personal setiap hari berlangsung, dan masing-masing pelaku sudah dapat mencermati setiap perilaku yang nampak dan ketika ini adalah aktivitas yang berulang, maka dapat diprediksi apa yang akan terjadi dari adanya sebuah keputusan yang diambil. Terjalinnya relasi antarpedagang juga dapat menumbuhkan ikatan diantara orang-orang yang tadinya tidak memiliki hubungan apapun, atau tidak saling mengenal. Akan tetapi kepemilikan los atau tempat jualan di pasar, biasanya dalam kurun waktu yang lama, baik sebagai penyewa maupun pemilik. Dari sana akan terjadi peningkatan sebuah hubungan, dan bagi pedagang menumbuhkan tali silaturahmi yang merepresentasikan kuatnya hubungan yang ada di pasar tradisional.

Dengan hubungan yang terjalin antapedagang, serta intensitas pertemuan yang tinggi, maka akan membangun hubungan yang lebih dari teman, bahkan bisa menjadi saudara. Kehidupan pedagang di pasar tradisional selama ini mampu menunjukkan eksistensinya, karena dapat membangun lokalitas dari sebuah daerah di mana pasar tradisional tersebut berada. Kondisi yang terlihat adalah terbentuknya relasi yang terpola dengan mengacu pada karakter masing-masing individu. Relasi sosial yang terbangun di pasar merupakan hasil dari interaksi dan terjadi hubungan timbal balik dari orang-orang yang terlibat dalam proses tersebut. Relasi terbangun secara berkelanjutan, sehingga seseorang mampu memprediksi tindakan orang lain yang memiliki keterkaitan dengan seseorang. Konteks hubungan antar sesama dipahami sebagai relasi, dan antara individu yang terlibat saling mempengaruhi, karena proses tersebut berlangsung terus menerus dan dalam kurun waktu yang relatif lama.

Pedagang dalam keseharianya tidak pernah terlepas dari perjumpaan dengan orang lain, sehingga memiliki kepedulian tinggi terhadap sesama pedagang maupun orang-orang di sekelilingnya. Sebagai 
sosok pribadi, maka akan berusaha memenuhi kebutuhannya untuk dapat mempertahankan hidupnya, salah satunya melalui komunikasi dengan melibatkan orang lain. Terjalinnya hubungan tersebut, juga memiliki tujuan tertentu dan juga membentuk aktivitas yang berulang. Konteks relasi di lingkungan pasar tradisional bersifat dinamis, karena memang relasi yang terbentuk dalam waktu lama mampu menciptakan sebuah pola dengan membawa peran masing-masing. Pedagang memiliki intensitas tinggi untuk membangun komunikasi di sela-sela aktivitas berdagang, baik dengan sesama pedagang, pembeli serta pelaku pasar lainnya. Pembeli yang juga memiliki ikatan kuat dalam kehidupan di pasar tradisional akan bisa membuka peluang untuk kembali berjumpa dengan pedagang yang sama. Ketersediaan barang dagangan di pasar tradisional, utamanya barang konsumsi harian menjadikan pasar memiliki perputaran yang cepat, sehingga tetap bisa memberikan barang yang berkwalitas kepada masyarakat.

Di antara pedagang dan pembeli, terbangun interaksi yang cepat dan bisa berkelanjutan, dan biasanya akan memunculkan kedekatan sebagai penjual dan pembeli. Inilah yang nanti akan memunculkan perilaku yang berulang, dengan nama sebagai pelanggan. Meskipun yang berjualan di pasar dengan komoditas yang sama jumlahnya tidak sedikit, tetap pembeli tersebut akan kembali ke pedagang langganan. Inilah relasi yang mampu dibangun oleh kedua belah pihak. Pasar merupakan wadah yang mempertemukan penjual dan pembeli untuk melakukan kegiatan jual beli. Saat ini kedudukan pasar tradisional memang dirasakan bisa tergantikan oleh kehadiran pasar modern, tetapi relasi yang dibangun sebagai ciri khas pasar masih belum bisa tergantikan.

Sofyan Assauri dalam Leksono (2009:152) mengemukakan bahwa pasar merupakan arena pertukaran potensial baik dalam bentuk fisik sebagai tempat berkumpul atau bertemunya para penjual dan pembeli, maupun yang berbentuk non fisik yang memungkinkan terlaksananya pertukaran, karena dipenuhi persyaratan pertukaran, diantaranya yaitu adanya minat dan citra yang baik serta data beli yang memadai. Dengan mekanisme tukar menukar langsung, dan penataan barang yang tidak disertai daftar harga, menjadikan penjual dan pembeli terikat dengan aturan yang tidak tertulis, yaitu berkomunikasi secara langsung untuk bisa menemukan kata sepakat harga komoditas yang diperjualbelikan. Meskipun kesan ini kadang merepotkan, tetapi hal ini adalah ciri khas yang belum luntur dan masih bisa bertahan hingga saat ini, meskipu era efisiensi, era cepat dan tepat semakin terbuka lebar di lingkungan masyarakat. Setidaknya kemampuan dalam bernegosiasi di kedua belah pihak mampu membuka mata semua orang, bahwa pasar tradisional adalah representasi sistem perdagangan dalam lingkup yang luas.

Para teoritikus ekonomi melihat struktur sosial, misalnya pasar dan sistem perdagangan, sebagai hasil yang muncul dari pengejaran secara rasional atas kepentingan individu dalam produksi, distribusi dan konsumsi (Scott, 2012:115). Sistem perdagangan di pasar tradisional selama ini menjadi nyata terlihat karena rutinitas yang hampir tiada henti, dan masih bisa dijumpai pasar yang sudah beraktifitas pada pukul 24.00 WIB, dan hal ini berlangsung setiap hari tanpa kata libur. Pedagang tidak hanya berpikir untuk mendapatkan keuntungan dalam proses jual 
beli, tetapi juga ada keinginan yang kuat untuk menarik pembeli dan mempertahankan sebagai pelanggan, dan tentunya hal ini akan didukung dengan kualitas barang yang diperdagangkan dan sikap positif dalam membangun relasi dengan pembeli. Proses produksi dan distribusi akan terus berlamgsung sejalan dengan semakin terpeliharanya lingkungan pasar tradisional. Pihak yang terlibat, baik pemerintah hingga pedagang sendiri semakin hari membangun pasar untuk mampu bersaing dengan kehadiran pasar modern.

Relasi yang muncul di pasar tradisional pada dasarnya meletakkan kepercayaan yang tinggi, baik dengan sesama pedagang ataupun dengan pihak lainnya. Perilaku yang mendukung hal itu nampak pada kebiasaan menitipkan dagangan ke teman tanpa ada perjanjian tertulis, menitipkan kios untuk ditinggal melakukan aktivitas lain, dan ini salah satu keunikan yang ada di pasar tradisional. Relasi tersebut semakin mengakar kuat karena dalam dunia pedagang, orang lain adalah bagian dari keluarga yang akan setiap saat akan memberikan bantuan dan memiliki empati yang tinggi terhadap kondisi yang dialami oleh pedagang lainnya.

Hubungan yang terbangun dengan kuat akan membawa seseorang menjadi lebih produktif dan juga akan memenuhi kebutuhan bersama akan sebuah interaksi. Untuk mendukung hal tersebut memerlukan komunikasi yang efektif, dengan indikator keterbukaan (openness) yang akan melibatkan penyikapan terhadap orang lain, pelaporan reaksi seseorang untuk menstimuli dengan jujur serta adanya kepemilikan perasaan (Curtis, 2000:36). Tanggungjawab tentu saja akan mengikuti dalam proses yang ada karena hubungan yang ada akan terus berlanjut atau memunculkan hubungan baru.

\section{Konsep Komunikasi Personal}

Individu dalam kehidupan sehari-hari tidak lepas dari komunikasi, dan mampu memaknai semua situasi berdasarkan perspektif yang dimilikinya, karena kemampaun sebagai pelaku komunikasi terasah setiap hari. Dalam kehidupan sosialnya, individu akan memandang pentingnya membangun komunikasi personal dengan individu lainnya sehingga bisa diterima oleh lingkungan dimanapun berada. Kedudukan individu juga juga tidak bisa terlepas dari sifat-sifat yang melekat dalam dirinya, dan akan bisa membedakan dengan orang lain. Karakteristik ini akan menunjukkan bagaimana seseorang berpikir dan bertingkah laku dalam berbagai situasi yang dihadapi. Memahami orang lain dalam tingkatan komunikasi personal akan menggabungkan cara berpikir dan bertindak serta situasi yang ada pada saat itu. Kondisi secara menyeluruh dalam situasi personal tidak hanya terbaca ketika perjumpaan secara face to face terjadi, tetapi dari pertemuan teersebut akan muncul kesan yang mendalam sehingga bertahan dalam frame seseorang dan hal ini akan terus diingat.

Komunikasi personal adalah bentuk komunikasi yang melibatkan simbolsimbol verbal dan non verbal. Setiap simbol yang digunakan menyampaikan suatu "konsep" yaitu ide umum, pola atau bentuk. Konsep yang ada terwujud dari pengalaman yang dimilikinya sehingga mampu menggambarkan sebuah objek secara detail. Masing-masing individu yang terlibat di dalamnya bisa merancang dan menyampaikan pesan dengan gaya yang dimilikinya. Individu tersebut juga berperilaku sesuai dengan apa yang 
dikehendaki. Fritz Heider dengan teori atribusinya dalam Morissan (2013:75) mengemukakan beberapa penyebab yang mendorong seseorang memiliki tingkah laku tertentu antara lain, penyebab situasional, adanya pengaruh personal, memiliki kemampuan, adanya usaha, memiliki keinginan, adanya perasaan, rasa memiliki, kewajiban dan diperkenankan.

Alasan-alasan tersebut akan kembali pada masing-masing individu sehingga ditemukan jawaban atas perilaku yang nampak. Nilai positif dari keinginan dan kesadaran untuk memahami alasan yang adalah bahwa dalam diri seseorang ada tingkatan yang berbeda untuk bisa paham diri sendiri serta orang lain. Bagaiamanapun juga membangun sebuah hubungan tanpa ada alasan biasanya berpengaruh terhadap keberlanjutan dari komunikasi yang dibangun kedua belah pihak. Membangun komunikasi personal dalam sebuah lingkungan terbangun juga dengan melihat norma yang berlaku, karena masing-masing individu membawa karakteristik yang tidak bisa hilang, sehingga yang menjadi benteng untuk memperkuat komunikasi adalah aturan yang berlaku di masyarakat.

Komunikasi personal melibatkan persepsi interpersonal, dan masing-masing orang akan memberikan penilaian terhadap berjalannya interaksi. Hal ini berangkat dari gambaran umum di masyarakat, bahwa pengalaman, karakter individu serta situasi sangat berpengaruh dalam interaksi. Setiap perubahan yang terjadi di lingkungan seseorang, akan menjadikan seseorang harus menyesuaikan diri dengan lingkungan tersebut, baik secara aktif maupun pasif. Perubahan yang terjadi kadang tidak dapat diprediksi, karena individu bisa secara cepat pula berubahan, apalagi mempertemukan dengan orang- orang baru. Tahapan perkenalan hingga penyesuaian diri tidak dapat dielakkan, dan menuntut seseorang untuk memainkan komunikasi personal secara efektif. Secara bertahap, penyesuaian diri akan ada, serta membentuk individu sebagai seseorang yang memiliki kebiasaan untuk memperlancar komunikasi yang berlangsung. Terwujudnya setiap keinginan individu untuk membangun komunikasi personal dengan individu lainnya adalah merupakan aktualisasi diri sebagai makhluk sosial. Tanpa disadari, kemampuan berkomunikasi tumbuh dan berkembang melalui interaksi di sebuah lingkungan.

Komunikasi personal secara kuantitatif bergantung pada jumlah orang yang terlibat. Sedangkan dari aspek kualitaif lebih menekankan pada hasil dari terbangunnya sebuah hubungan secara produktif dan ada keberlanjutan sehingga mengarah pada komunikasi efektif. Komunikasi personal juga sampai pada tahapan di mana seseorang akan merancang sebuah pesan yang berhubungan dengan dirinya sendiri untuk diinformasikan kepada orang lain. Keahlian dalam komunikasi personal menjadi penting karena akan ada penilaian secara personal dan memainkan simbol-simbol non verbal sehingga dapat dimaknai secara langsung. Keterlibatan orang lain ini akan bisa menyentuh pada informasi yang sifatnya pribadi, karena komunikasi personal melibatkan emosi, memunculkan empati, dan persepsi.

Pembentukan hubungan dalam tatanan personal di lingkungan bisnis menjadi penting karena akan mempengaruhi perilaku individu, serta untuk memenuhi kebutuhan individu. William Schutz dalam Curtis (2000:33) menyatakan bahwa kebutuhan dasar dalam 
memenuhi kebutuhan secara personal terdiri dari inklusi (dilibatkan), kontrol, dan afeksi (kasih sayang). Kebutuhan ini menekankan bahwa perilaku seseorang akan juga berkaitan dengan interaksi dengan orang lain. Kebutuhan tersebut adalah hal yang mendasar dan kesemuanya akan menjadi baik jika kebutuhan yang ada berada pada posisi yang seimbang. Masingmasing individu pastinya akan memiliki tingkatan yang berbeda pada kebutuhan tersebut, kesadaran yang juga muncul di pribadi masing-masing, bisa memang disadari sepenuhnya atau juga muncul dari proses interaksi yang dibangun dengan individu lainnya, karena komunikasi personal lebih bisa menyentuh pada diri masing-masing individu.

\section{Kontribusi Interaksionisme Simbolik}

Teori interaksionisme simbolik merupakan salah satu perspektif teori dalam sosiologi yang memiliki akar pemikiran yang beragam (Haryanto, 2013:69). Sejumlah pemikir yang tergabung dalam pendekatan ini antara lain G.H Mead, Charles H Cooley, William I Thomas, Herbert Blumer dan Erving Goffman Akar historis utama pendekatan ini adalah Pragmatisme dan Behaviorisme. Ada tiga hal yang penting dari interaksionisme simbolik. 1) memusatkan perhatian pada interaksi antara aktor dan dunia nyata; 2) memandang baik aktor maupun dan dunia nyata sebgai proses dinamis dan bukan sebagai struktur yang statis; 3) arti penting yang dihubungkan kepada kemampuan aktor untuk menafsirkan kehidupan sosial (Ritzer, 2007:266).

Karakteristik dari interaksionisme simbolik adalah suatu hubungan yang memang terjadi secara alami antara manusia dalam masyarakat dan hubungan masyarakat dengan individu, dan interaksi yang terjadi berkembang melalui simbolsimbol yang diciptakan (Wirawan, 2014:109). Interaksi yang terjalin tersebut dilakukan secara sadar, sehingga masingmasing mampu mencurahkan memaknai apa yang melekat dalam diri seseorang, khususnya dari pihak yang terlibat dalam interaksi.

Salah satu yang penting dari teori ini adalah pemikiran Mead yang berkaitan dengan keutamaan dan prioritas dunia sosial. Dari dunia sosiallah kesadaran, pikiran, diri muncul. Unit yang paling mendasar dalam pemikirannya adalah tindakan yang mencakup empat tahap yang berhubungan secara dialektis, ada impuls, persepsi, manipulasi dan penyelesaian (Ritzer, 2012:660). Suatu tindakan sosial setidaknya meliput dua orang atau lebih, dan mekanisme dasar tindakan sosial adalah gerak isyarat. Manusia adalah makhluk yang mampu mengembangkan isyarat-isyarat, sehingga manusia mampu memahami dan mengembangkan isyarat tersebut. Mead adalah tokoh yang berjasa dan memiliki kontribusi besar, pemikirannya tentang hubungan antara interaksi sosial dan proses-proses mental subjektif seperti konsep diri yang berhubungan dengan komunitas atau masyarakat yang lebih besar. Perspektif Mead adalah tentang bagaimana pengetahuan berkembang melalui proses adaptasi terhadap lingkungan.

Mead pada dasarnya tertarik pada interaksi, yang di dalamnya terdapat isyarat nonverbal dan makna dari suatu pesan verbal yang dijelaskan bisa mempengaruhi pikiran orang-orang yang terlibat dalam interaksi. Setiap isyarat yang ada, akan dimaknai berdasarkan kesepakatan bersama diantara pihak yang terlibat, karena interaksi merupakan satu bentuk 
simbol yang mempunyai arti penting ( $a$ significant symbol) sehingga tidak bisa lepas dari pandangan serta pemaknaan secara keseluruhan (Siregar, 2011:102).

Pemikiran Mead ini membawa kontribusi positif bagi masyarakat, khususnya pada tahapan memahami setiap proses yang dijalankan oleh manusia, karena setiap tindakan yang ada melibatkan simbol-simbol, dan hal tersebut memunculkan tanggapan serta penilaian berdasarkan kesepakatan bersama. Munculnya kesepakatan ini dilandasi bahwa bentuk perilaku yang melekat dalam diri seseorang adalah representasi dari pengalaman, pengetahuan yang diperoleh manusia. Masing-masing individu yang memberikan makna serta tanggapan terhadap simbol yang ada merupakan hasil dari pembelajaran dan interaksi yang dibangun. Sebagai langkah yang ditempuh adalah sebuah tahapan untuk mengkomunikasikan simbol-simbol yang ada di sekitarnya, baik secara verbal maupun perilaku non verbal. Kemampuan manusia inilah yang pada akhirnya menjadi sebuah keistimewaan tersendiri dibandingkan dengan makhluk hidup lainnya.

Salah satu ciri khas interaksi simbolik terletak pada intisari manusia dalam proses saling menterjemahkan dan saling mendefinisikan tindakannya. Tahapan dari setiap proses yang ada akan menunjukkan kuatnya hubungan antarmanusia sehingga keberlanjutan menjadi tujuan yang terencanakan namun tidak harus diungkap secara verbal. Komunikasi tersebut akan berlanjut dalam tingkatan yang mendefinisikan simbol lebih beragam lagi, karena satu sama lain mulai bisa memberikan penafsiran akan karakter yang ada pada diri seseorang. Penggunaan simbol dan interpretasi yang ada, akan menuju pada pemahaman serta kesepakatan bersama.

Teori interaksionisme simbolik dikonstruksikan atas sejumlah ide-ide dasar. Ide dasar mengacu pada masalahmasalah yang tumbuh di masyarakat, interaksi sosial, obyek, manusia sebagai pelaku, tindakan manusia dan interkoneksi dari saluran-saluran tindakan (Soeprapto, 2002:142). Manusia adalah makhluk yang aktif dan kreatif sehingga memiliki kemampuan berkomunikasi dengan menggunakan simbol-simbol serta mampu memaknai dan mengaktualisasikannya dalam kehidupan sehari-hari. Dengan simbol yang ada, manusia juga mampu bagaimana harus bertindak dan bereaksi terhadap lingkungan, karena simbol-simbol yang melekat adalah simbol yang dekat dengan keseharian. Dapat dikatakan bahwa penggunaan dan pemaknaan terhadap simbol tersebut adalah bagian dari kebutuhan manusia yang akan membawa pada kehidupan berkelompok.

Kehidupan sebagai individu, berkelompok dan bermasyarakat adalah bagian dari sosialisasi yang memungkinkan manusia membentuk kehidupan sosialnya. Harapan untuk bisa bersosialisasi secara berkelanjutan, secara sadar atau juga tidak akan memunculkan respon yang juga bisa ditafsirkan oleh orang lain. Manusia pembuat simbol, dan menafsirkan serta mempertukarkan kembali dalam interaksi, akan semakin bermakna jika lingkungan sekitar juga mengartikan setiap simbol yang ada dalam diri manusia. Simbol merupakan objek sosial, yang mana dalam sebuah interaksi sosial, simbol itu merepresentasikan sesuatu yang biasanya disepakati oleh masyarakat. Kegiatan manusia sebagai bagian masyarakat, akan membawa simbol-simbol, kebiasaan, aturan dan kesemuanya itu adalah satu 
kesatuan yang tidak bisa dipisahkan. Bangunan masyarakat terdiri dari individuindividu yang kreatif, sehingga perilaku yang nampak merupakan aktualisasi diri sebagai manusia seutuhnya. Untuk bisa menyikapi lingkungan dengan baik, maka manusi tergerak untuk berbagi cerita serta melibatkan orang lain dalam kesehariannya, meskipun sebagian kecil dari aktivitas tersebut. Keunikan yang ditonjolkan masing-masing individu tidak terlepas dari pengalaman yang membentuk karakter seseorang.

Lingkungan yang membentuk perilaku seseorang memiliki kompleksitas simbol yang secara nyata menempatkan manusia sebagai makhluk yang kreatif, dan dengan kemampuannya akan dengan cepat memberikan adaptasi dalam setiap situasi yang dihadapi. Reaksi yang dibangun juga muncul dalam tahapan yang terstruktur, dengan melakukan sebuah penilaian dan pertimbangan akan rangsangan yang muncul dari luar. Kemampuan yang dimiliki manusi akan menuntun untuk memberikan sebuah kesadaran bahwa sebelum memulai suatu tindakan, ada proses untuk berpikir serta memberikan penilaian terhadap tindakan yang akan diwujudkan.

Kondisi inilah yang memberikan pemaknaan bahwa dalam kehidupan manusia tidak bisa terlepas dari simbolsimbol serta sejalan dengan kemampuan yang dimiliki manusia dalam menterjemahkan, memaknai serta memunculkan simbol baru dalam sebuah interaksi dengan tujuan terwujudnya kesepakatan bersama.

\section{HASIL DAN PEMBAHASAN}

Contemporaries symbolic pada perilaku bisnis pedagang di lingkungan pasar tradisional merupakan sebuah cermin bagi masyarakat bahwa lingkungan di mana interaksi terwujud, banyak melibatkan simbol-simbol yang semakin kompleks, sehingga dinamika pada berjalannya pertemuan antarindividu harus terdukung dengan kemampuan dalam memahami simbol yang ada. Dari kesadaran dalam diri manusia bahwa tutur kata, perilaku, gerakan yang mendukung komunikasi verbal adalah wujud dari konsep simbol itu sendiri.

Simbol belum mampu dilepaskan dari kehidupan manusia, hal ini disadari bahwa salah satu kebutuhan manusia adalah kebutuhan untuk menggunakan lambanglambang dalam setiap tindakan yang ada. Keunikan yang ditampilkan manusia sebagai makhluk sosial adalah dasar bagi tumbuhkembangnya simbol beserta pemaknaannya. Kemampuan menginterpretasikan simbol tersebut kan semakin beragam apabila individu juga semakin memperlebar cakupan interaksinya, baik dengan lingungan yang sama maupun yang berbeda. Kemampuan ini akan semakin terasah apabila menemukan simbol baru yang belum pernah dipahami sebelumnya, sehingga hal ini harus terdukung dengan keinginan untuk mengkomunikasikan secara terbuka. Kejujuran dalam proses interaksi akan membangun jiwa-jiwa yang mampu memaknai simbol secara positif, tertapi dengan realitas yang semakin komprehensif, maka manusia harus mewujudkan pemaknaan yang ada secara bersama.

Simbol tersebut tercermin dari media yang digunakan, pakaian yang sehari-hari melekat dalam aktivitas di lingkungan pasar, alat transportasi yang digunakan dan juga aksesoris yang melekat dalam kesehariannya. Simbol yang terlihat ini bisa dimaknai oleh orang lain serta 
menunjukkan karakter yang ada pada diri pedagang. Simbol melekat dalam aktivitas keseharian pedagang, karena rutinitas akan terdukung oleh fasilitas yang ada.

Aktivitas yang dilakukan pedagang tidak hanya mempertemukan pedagang dengan sesama pedagang, tetapi yang utama adalah adalah pertemuan dengan pengunjung serta pembeli yang memiliki karakteristik beragam, karena perjumpaan dengan orang yang berbeda setiap hari. Pedagang seakan dituntut untuk mampu berkomunikasi sehingga proses jual beli dapat berlangsung dengan lancar dan hasil akhir dari transaksi tersebut sesuai dengan harapan kedua belah pihak. Kemampuan berkomunikasi tidak terlepas dari kemampuan untuk memaknai simbolsimbol yang muncul dari proses tawar menawar antara penjual dan pembeli. Pedagang akan terbiasa membaca situasi yang diciptakan dengan kehadiran pembeli.

Simbol-simbol yang ada tersebut memiliki peran penting untuk memunculkan status dari pedagang. Tidak hanya para pedagang saja yang saling memberi status, tetapi bagi pihak lain juga akan bisa menilai kehidupan pedagang berdasarkan simbol yang ada. Saat ini pedagang pasar tradisional tidak bisa jauh dari alat telekomunikasi dan dengan kehadirannya bisa menunjang pedagang dalam beraktivitas. Alat komunikasi ini dalam penggunaannya di kalangan pedagang adalah untuk memonitor harga komoditas yang diperdagangkan, untuk menerima pesanan serta sebagai sarana berkirim kabar satu sama lain. kemudahan yang diperoleh pembeli dan pedagang saat ini menunjukkan bahwa pergerakan perilaku pedagang dan pembeli memiliki intensitas dalam mewujudkan interaksi yang berkelanjutan. Peran yang dibangun diantara keduanya pada tahapan awal sebagai pedagang dan pembeli, serta bisa meningkat dengan melibatkan saling tukar informasi yang sifatnya lebih personal. Bercerita tentang keluarga, saudara serta tetangga adalah salah satu indikator untuk melihat kedekatan yang dibangun diantara pedagang dan pembeli. Alat komunikasi yang digunakan, khususnya hand phone (HP) telah mengubah perilaku dan kebiasaan hampir seluruh masyarakat berbudaya (Katili, 2015:25). Butuh waktu dalam mengubah kebiasaan masyarakat, dan terbukti bahwa komunikasi yang terbatas mampu terhubung dengan munculnya salah satu produk/teknologi yang dirancang oleh manusia. Ketika teknologi hand phone baru muncul, bisa menunjukkan status sosial dari sekelompok manusia, dan pergerakan yang sangat cepat, "perang" produk, menjadikan teknologi ini bisa menduduki semua posisi yang ada di masyarakat. Dalam arti kemudahan kepemilikan, harga yang kompetitif, fasilitas yang disuguhkan, menjadikan produk ini lekat dengan semua lapisan masyarakat.

Lingkungan pasar sudah tidak asing lagi bagi sebagian masyarakat, karena keberadaannya tidak dapat dipisahkan dari kehidupan masyarakat. Di beberapa wilayah, pergerakan pasar tradisional sebagai tempat perputaran ekonomi menjadi tempat yang bisa membawa kemanfaatan bagi masyarakat sekitar, baik yang berprofesi sebagai pedagang maupun sebagai pembeli. Pedagang memiliki rutinitas yang tinggi untuk memberikan pelayanan kepada pembeli, yang dibuktikan dengan rutinitas berdagang setiap hari.

Sebagian besar pasar tradisional dikelola oleh pemerintah dan mendapat perhatian guna mengupayakan adanya perbaikan dari segala bidang, baik dari fisik 
maupun sistem pasar yang menekankan pada keberlangsungan pasar untuk memenuhi hajat hidup masyarakat. Seiring waktu, keberadaan pasar tradisional seakan-akan dituntut untuk mengikuti perkembangan zaman dalam hal pengelolaan serta fasilitas umum. Banyak faktor yang menjadikan pasar tradisional masih harus berkutat dengan kondisi yang ada dan jauh dari harapan masyarakat. Untuk itu diperlukan tekad yang kuat dan kebersamaan untuk mengelola pasar agar bisa menjadi lebih baik dan membuat nyaman bagi semua orang. Perkembangan wilayah-wilayah di Indonesia tiap tahun kian pesat, hal ini tentu berdampak pada tuntutan kebutuhan masyarakat yang semakin meningkat dan kompleks. Salah satu tempat yang bisa memenuhi kebutuhan masyarakat adalah pasar tradisional. Pasar memang secara nyata dipahami sebagai tempat untuk terjadinya proses jual beli, di mana pedagang dapat secara langsung menjual barang dagangan, dan pembeli dapat memilih sesuai dengan apa yang dikehendaki. Ketersediaan barang dagangan yang semakin lengkap akan membuat pembeli merasa senang, karena dengan satu kali datang akan memperoleh barang yang diinginkan.

Bisnis di pasar tradisional identik dengan berjualan untuk memperoleh keuntungan sedikit demi sedikit untuk mempertahankan pembeli sehingga bisa bersattus sebagai pelanggan. Berjualan di pasar tradisional dapat dikatakan menguntungkan dan berpeluang untuk menciptakan masa depan yang semakin baik atau meningkat dari sebelumnya. Sararan konsumen jelas, dalam arti bahwa konsumen akan berbelanja untuk memenuhi kebutuhan sehari-hari dengan harga yang murah tetapi kualitas barang yang tidak kalah dengan pasar modern.
Pasar tradisionl adalah lokasi yang strategis untuk memulai usaha meskipun pelaku sudah banyak. Masing-masing akan bisa berpeluang mendapatkan konsumen, dengan keunggulan pada jenis komoditas serta kualitas yang tidak diragukan lagi.

Lokasi pasar tradisional biasanya berada di tempat srtaegis, mudah dijangkau masyarakat serta memiliki cakupan yang luas. Pandangan yang ada selama ini adalah pasar tradisional tidak pernah sepi. Dengan jumlah pedagang yang semakin meningkat, pengunjung yang selalu memadati area pasar, jenis komoditas yang semakin beragam menjadikan pasar sebagai tempat yang menjanjikan untuk memulai atau mempertahankan usaha yang sudah ada. Lokasi memang menentukan sukses tidaknya usaha, produk sebagus apapun jika tidak terdukung oleh tempat berjualan yang tepat, maka akan sulit mendatangkan pembeli. Hal inilah yang pada akhirnya membutuhkan keterlibatan dari pihakpihak yang akan mendukung keberlangsungan pasar tradisional. Penataan kios, los atau bedak sedemikan rupa, akses yang mudah, keamanan, kebersihan tempat adalah tuntutan yang harus mampu diwujudkan untuk bisa memberikan pelayanan yang baik kepada konsumen. Bagaimanapun juga eksistensi pasar tradisional menjadi tanggungjawab bersama semua pihak yang terlibat di lingkungan pasar, baik pedagang, konsumen hingga pengelola pasar.

Lingkungan pasar tradisional pada umumnya menggambarkan suatu hubungan antara individu-individu yang ada di masyarakat. Sejauh ini, struktur sosial pasar terbentuk dari tindakan berdasarkan alasan tertentu, tidak hanya atas nama kekerabatan, tetapi juga bisa muncul sebuah hubungan dengan alasan perekonomian, berdasarkan kesamaan 
antara individu satu dengan yang lain serta bisa muncul dari persamaan asal daerah, budaya dan lainnya. Kehidupan bermasyarakat sendiri semakin teratur, karena msing-masing bisa membangun peran dengan baik dan mampu berperilaku sesuai dengan aturan yang ada di masyarakat. Perkembangan struktur sosial di masyarakat akan selalu berkembang dan bisa berubah karena akan proses yang berubah, dan hal ini secara berkesinambungan berpengaruh terhadap pola yang sudah ada, bahkan bisa membentuk sebuah pola baru.

Lingkungan pasar tradisional yang didiami oleh pedagang mampu memunculkan kedekatan secara personal, hal ini bisa menentukan keberlangsungan interaksi baik antarpedagang maupun pedagang dengan pembeli. Hubungan sosial yang terbangun tersebut adalah sebuah kunci bagi masyarakat pedagang untuk melangsungkan aktivitas berdagang. Masyarakat pedagang hingga saat ini terus mengalami perkembangan, tidak hanya pada komoditas yang diperdagangkan, tetapi secara pribadi memiliki karakteristik yang membedakan dengan yang lain serta terbangunnya kemampuan berkomunikasi dengan tidak meninggalkan ciri khas yang selama ini melekat.

Karakteristik tersebut terbawa pada perilaku keseharian pedagang dengan mengedepankan cara berkomunikasi, baik di lingkungan pasar maupun lingkungan lainnya. Dengan membawa perilaku tertentu, pedagang bisa dikenal dengan baik oleh pedagang yang lain atau oleh pembeli degan ciri khas yang melekat dalam dirinya dan terbawa dalam situasi komunikasi tatap muka. Intensitas komunikasi personal yang tidak bisa hilang dari lingkungan pasar tradisional memang membawa nilai positif tersendiri, di mana masing-masing orang akan menunjukkan empati hingga simpati yang akhirnya bisa mendekatkan satu sama lian. Secara signifikan, perilaku pedagang ini memang mampu memainkan beberapa peran sekaligus, karena di pasar tradisional pedagang juga bisa menjadi pembeli di tempat lain.

Begitu kuatnya perjumpaan dengan medium tatap muka langsung (face to face) antara penjual dan pembeli, mewujudkan tatanan komunikasi yang terstruktur tanpa mengekang aktivitas serta perjumpaan yang sama setiap hari. Melalui sapaan, gaya berkomunikasi, atribut yang melekat dalam masing-masing pribadi yang ada menegaskan bahwa lingkungan pasar tradisional merepresentasikan kehidupan masyarakat yang komprehensif. Tindakan tersebut adalah sebuah gambaran nyata yang tidak dapat dipungkiri membentuk karakter masyarakat pasar dengan simbolisasi yang beragam. Perilaku yang nampak bukanlah sebuah tindakan yang dibuat dengan paksaan, tetapi membawa nilai kejujuran sebagai manusia yang samasama saling membutuhkan untuk mencapai tujuan bersama.

\section{PENUTUP}

\section{Kesimpulan Dan Saran}

Komunikasi yang dibangun oleh pedagang di lingkungan pasar tradisional, khususnya komunikasi personal merepresentasikan kehidupan pedagang sebagai individu yang kompleks. Tindakan dari pedagang adalah wujud totalitas yang tidak terstruktur dan akan selalu berubah seiring dengan situasi yang dihadapi. Tetapi ada satu hal yang menarik bahwa perilaku yang nampak mampu dipahami oleh orang lain yang terlibat dalam situasi komunikasi. Proses penyampaian dan pemaknaan pesan bersumber dari kesan awal yang dimunculkan oleh komunikator dan 
komunikan. Hal ini terlihat dari simbolsimbol yang menyertainya sebagai peneguh pesan yang disampaikan secara verbal. Lingkungan pasar tradisional sarat dengan komunikasi personal, karena keterlibatan pedagang dan pembeli secara langsung, atau juga komunikasi yang dibangun antar pedagang.

Salah satu cara yang digunakan untuk menjaga harmonisasi di lingkungan pasar tradisional adalah dengan membangun, serta mengoptimalkan komunikasi efektif dengan berbagai pihak. Terlepas dari strategi komunikasi yang dipilih, akan bermuara pada kesamaan makna sehingga tujuan komunikasi yang tidak terucap bisa diraih oleh kedua belah pihak. Upaya yang dilakukan untuk menopang peningkatan kualitas interaksi di lingkungan pedagang adalah memberikan informasi yang tidak berlebihan, menunjukkan kejujuran yang tidak semu, dan menafsirkan pesan dengan baik.

Simbol-simbol yang begitu dekat pada setiap transaksi terwujud dari tindakan yang berulang, bisa dengan orang yang sama maupun yang beda, karena lingkungan pasar tradisional sebagai sebuah wadah yang mempertemukan individu-individu dengan berbagai karakter yang unik. Hal ini merupakan nilai positif yang muncul di lingkungan pasar tradisional.

\section{Daftar Pustaka}

Boden, Deirdre. 1999. Symbolic Interaction and Cultural Studies. In: Becker, Howard \& McCall, Michal M (eds) The University of Chicago Press. Chicago \& London

Curtis, Dan B. Floyd, James J. Winsor, Jerry L. Komunikasi Bisnis dan Profesional. Remaja Rosdakarya. Bandung
Haryanto, Sindung. 2013. Spektrum Teori Sosial dari Klasih hingga Postmodern. Ar-Ruzz Media. Jogjakarta

Leksono, S. 2009. Runtuhnya Modal Sosial, Pasar Tradisional Perspektif Emic Kualitatif. Citra. Malang

Morissan. 2013. Teori Komunikasi Individu Hingga Massa. Kencana Prenada Media. Jakarta

Gerungan, W.A. 2004. Psikologi Sosial. Refika Aditama. Bandung

Katili, Hwa. 2015. Ekonomi Kaki Lima, Notulensi Dongeng Ekonomi Yang Diekstrak Dari Media. Omar Niode Foundation

Katovich, Michael A. Miller, dan E. Hintz, Robert A. 2002. Studies in Symbolic Interaction Volume 25. In: Denzin, Norman K (ed). JAI. An Imprint of Elsevier Science. Amsterdam

Ritzer, George. 2012. Teori Sosiologi. Dari Sosiologi Klasik Sampai Perkembangan Terakhir Postmodern. Edisi Kedelapan 2012. Pustaka Pelajar. Yogjakarta

Ritzer, George. Goodman, Douglas J. 2007. Teori Sosiologi Modern. Kencana Prenada Media. Jakarta

Scott, John. 2012. Teori Sosial, MasalahMasalah Pokok dalam Sosiologi. Pustaka Pelajar. Jogjakarta

Siregar, Nina Siti Salmaniah. 2011. Kajian Tentang Interaksionisme Simbolik. Jurnal Ilmu Sosial Fakultas ISIPOL UMA. ISSN: 2085-0328. Perspektif/Volume 4/Nomor 2/ Oktober 2011.

http://ojs.uma.ac.id/index.php/pers pektif/article/download/86/46.

Diakses pada tanggal 5 Juli 2017, puul 19.23. 
JURNAL NOMOSLECA

Volume 3, Nomor 1, April 2017

Soeprapto, Riyadi HR. 2002.

Interaksionisme Simbolik

Perspektif Sosiologi Modern.

Averroes Press bekerja sama

dengan Pustaka Pelajar. Malang

Wirawan, I.B. 2014. Teori-Teori Sosial

Dalam Tiga Paradigma. Kencana

Prenada Media. Jakarta. 